\title{
First record of Placozoa from the Gulf of Mexico
}

\author{
Primer registro de Placozoa para el Golfo de México
}

\author{
Tania Shazel Ortega Tecuatl ${ }^{1}$, Rodrigo Arreola Alemón² and Rodrigo Cuervo González \\ ${ }^{1}$ Laboratorio de Evolución y Embriología, Facultad de Ciencias Biológico y Agropecuarias Universidad Veracruzana. Carretera Tuxpan-Tampico Km 7.5 Tuxpan, \\ Veracruz, 92860. México \\ ${ }^{2}$ Departamento de Psiquiatría Genética, Instituto Nacional de Psiquiatría, "Ramón de la Fuente". Calzada México-Xochimilco 101, Colonia Lorenzo Huipulco, \\ Tlalpan, 14370. CDMX, México \\ e-mail:rodcuervo@uv.mx
}

Recibido: 24 de diciembre de 2016. Aceptado: 23 de septiembre de 2017.

Ortega Tecuatl T. S., R. Arreola Alemón and R. Cuervo González. 2017. First record of Placozoa from the Gulf of Mexico. Hidrobiológica 27 (3): 429-432. D01: 10.24275/ uam/izt/dcbs/hidro/2017v27n3/Cuervo

\section{ABSTRACT}

Background. Placozoa is a phylum with only one species:Trichoplax adhaerens (F. E. Schulze, 1883); recent genetic studies suggest, however,that several haplotypes inhabit tropical and subtropical waters around the world. Placozoans have been found usually close to littoral zones where mangrove forests occur. Goals. To provide the second record of this species from the coasts of Mexico and describe a new filament structure observed in the upper epithelium. Methods. Photographic images were taken of Placozoans found in glass slides introduced in marine aquariums. Some specimens were collected and stained with Mito Tracker, DAPI and Lyso Tracker fluorescent dyes according to the manufacturer instructions. Results. Puerto Morelos in the Mexican Caribbean Sea and Florida in the Atlantic coast are the closest places to the Gulf of Mexico were Placozoans have been recorded. We report here the first record of Trichoplax adhaerens in the Gulf of Mexico. The organisms were found in sea water aquariums built with materials, water, and invertebrates obtained from the Tuxpan reef $(21.016667 \mathrm{~N}$, 97.186389 W), an emerged platform that belongs to the Lobos-Tuxpan Reef System. Conclusions. This finding is the first record of Trichoplax for the coasts of the western Gulf of Mexico and includes the description of a filament structure in the upper epithelium not reported before.

Key words: Gulf of Mexico, Placozoa, Trichoplax adhaerens.

\section{RESUMEN}

Antecedentes. Placozoa es un phylum con solo una especie: Trichoplax adhaerens (F. E. Schulze, 1883); sin embargo, estudios genéticos recientes sugieren que varios haplotipos habitan en aguas tropicales y subtropicales alrededor del mundo. Generalmente los Placozoarios han sido encontrados cerca de zonas litorales donde hay bosques de manglar. Objetivos. Proporcionar el segundo registro de esta especie para las costas de México y describir una nueva estructura filamentosa observada en el epitelio superior. Métodos. Se tomaron imágenes fotográficas de Placozoarios hallados en laminillas de vidrio introducidas en acuarios marinos. Algunos especímenes fueron colectados y teñidos con los colorantes fluorescentes mitotracker, DAPI y lysotracker siguiendo las instrucciones de los fabricantes. Resultados. Puerto Morelos en el mar Caribe mexicano y la costa atlántica de Florida, son los lugares más cercanos al Golfo de México donde los Placozoarios han sido registrados. Aquí reportamos por primera vez a Trichoplax adhaerens en el Golfo de México. Los organismos fueron encontrados en acuarios marinos construidos con materiales, agua e invertebrados obtenidos del arrecife Tuxpan (21.016667 N, 97.186389 0), una plataforma emergente que pertenece al sistema arrecifal Lobos-Tuxpan. Conclusiones. Este hallazgo representa el primer registro de Trichoplax para las costas del Oeste del Golfo de México, e incluye la descripción de una estructura filamentosa en el epitelio superior no reportada antes.

Palabras claves: Golfo de México, Placozoa, Trichoplax adhaerens.

Placozoans are the simplest free-living animals and probably the most primitive Eumetazoan. With only six cell types organized as an irregular ciliated flat disc (Smith et al., 2014), their body plan is comprised of marginal versus interior and top versus bottom regions and no symmetry axes are evident. These organisms posses san upper and lower epithelium -with no basal lamina or extracellular matrix- that enclose a loose network of interconnected branched cells called fiber cells. Discovered by F. E. Shultz in the $19^{\text {th }}$ century, Trichoplax adhaerens is the only described species of the phylum Placozoa (Schulze, 1883). Its simplicity and taxonomic basal position make Placozoans unique organisms to study early metazoan evolution. A recent phylogenomic study 
that compared the relationships of early diverging metazoan lineages, unambiguously placed Porifera as the sister group of all Metazoans; Ctenophora emerged as the second branch of Eumetazoa and Placozoa resulted the basal taxon of the clade Placozoa+Cnidarian+Bilateria (Simion et al., 2017).

Placozoans have been found in tropical and subtropical waters around the world (Eitel et al., 2013) and despite their identical morphology, molecular studies imply the existence of many species and different lineages occurring sympatrically (Voigt et al., 2004). In one extensive study about the biodiversity found in the Gulf of Mexico,the phylum Placozoa is listed as part of the species of several phyla found (Felder \& Camp, 2009); however, no additional data, formal description, or scientific publication was done.

Here, we describe findings dozens of Placozoans adhered to the glass walls of a seawater aquarium after performing several partial changes of water obtained from the Tuxpan reef in June and July 2015. The Tuxpan reef is an emerged platform located $12 \mathrm{~km}$ from the coastline in the Southwest of the Gulf of Mexico.This littoral region has estuarine waters with mangrove swamps an Tuxpan harbour is situated at the mouth of the Tuxpan. River. It is known that the ocean currents in the Gulf of Mexico transports water along the coastal line from the Southeast (Campeche Bank) to the Southwest (Zavala-Hidalgo et al., 2003). Parallel to this coastal line, several reefs form an ecological corridor (Ortiz-Lozano et al., 2013), which are inhabited by species that arise from the Caribbean Sea. Therefore, the Placozoans we found may be a native population but derived from the Caribbean zone, probably related with the H1-4 haplotypes (Grell \& López-Ochoterena, 1987; Voigt et al., 2004). The aquarium that harbors the Placozoans is three years old and has colonies of corals, sponges, and sea grass beds that were obtained from the same reef. No synthetic water, exotic species, or commercial food for corals were introduced in the aquarium. The setup, with a volume of $400 \mathrm{~L}$, has a sump filter with live rock obtained from the reef zone and the temperature is maintained at $26-28{ }^{\circ} \mathrm{C}$. Three organisms were fixed in $4 \%$ glutaraldehyde in seawater and registered as Voucher specimens in the National Collection of Phylum Porifera, UNAM (catalog number CNPGG-1488, CNPGG-1489, and CNPGG-1490).

Most Placozoans were around $600 \mu \mathrm{m}$ in diameter although some smaller or larger specimens were also found (ranging from 200 to 1500 $\mu \mathrm{m})$. They showed an irregular "hairy plate" form ("tricho-plax") and gliding movement (Figs 1a-b). The characteristic birefringent vesicles or "shiny spheres" of this taxon were clearly observed on the upper side (Fig. 1c), except in the outer margin where upper and lower epithelium apposed (Fig. 1e). Images also show yellow bodies scattered below the upper epithelium containing vacuoles of digested algae (Fig. 1c). The Trichoplax moved constantly with amoeboid movements but without a particular direction; at intervals, the margins folded such that the lower epithelium formed transient grooves (Fig. 1a, arrows). We observed that sometimes one groove was extended from side to side and the Placozoan slides on its own lower epithelium (Fig. 1f). Occasionally, the edges rose and enclosed the upper epithelium for a few minutes (Fig. 1g-k).

We observed two of the four modes of reproduction reported in the literature: binary fission (Fig. 1d) and flagellated, hollow swarmers (Figs 1I-n) (Thiemann \& Ruthmann, 1991). By scraping the glass walls of the aquariums, spinning swarmers were obtained mostly adhered to algae. On glass slides introduced in the aquarium and examined one week later, we observed one spherical form of Trichoplax that slowly rotated, maintaining a strong adhesion to the substrate without signs of degeneration (Fig. 10). This spherical Trichoplax appears to be of the type previously reported as "hollow sphere with interior compartment" (Thiemann \& Ruthmann, 1990). Interestingly, on other glass slides we captured some Trichoplax with a long protuberance in the upper side (Figs. 1p-q). This structure lasts for several hours but disappears after 24h. It seems to be the same slender threadlike extension of around $1 \mathrm{~mm}$ long that was often observed in those Trichoplax living in areas where the water flow is stronger (Fig. 1r). This filamentous structure swings with the stream of water and maintains a constant size for hours; it is probably used to sense the currents of water. To our knowledge, this structure has never been reported before. Finally, we assayed fluorescent dyes to stain specific cellular structures, such as the nucleus (DAPI), mitochondrion (Mito Tracker, Molecular Probes) (Fig. 1s), and acidic organelles (Lyso Tracker, Molecular Probes) (Fig. 1t) to confirm the staining patterns reported in other studies (Smith et al, 2014).

Placozoans grew and multiplied well with these aquarium condictions and grazed upon Feldmannia sp. algae that grew on the glass walls (Fig. 1b). They shared a micro-ecosystem with an assemblage of small organisms such as Vorticella, ciliates, heliozoans, nematodes, metamorphosing sponges, and cyanobacteria. Ciliates and nematodes made contact randomly with Placozoans but they did not elicit any specific response or reaction.

We have been able to maintain a healthy ecosystem in the marine aquarium with the appropriate conditions to obtain a constant supply of Trichoplax, making it possible to perform other experiments, for example, molecular studies to determine the haplotype of this strain.

\section{ACKNOWLEDGMENTS}

The authors thank Dr. Christopher Wood for his careful reading of the manuscript. Also, we thank Dra. Patricia Gómez of the Instituto de Ciencias del Mar y Limnología, UNAM, for helping us with the Voucher specimens. This work was supported by Grant 151757 from the Consejo Nacional de Ciencia y Tecnología (CONACyT).

Figures 1a-t. Placozoans confined in marine aquariums. a) Living Trichoplax showing the characteristic epithelial grooves and irregular shape. b) Gliding Trichoplax adhered to Feldmannia sp. algae. c) The characteristic yellow vacuoles of digested algae (arrow) and the shiny spheres (arrow head). d) Asexual reproduction by binary fission. e) Detail of the upper marginal region showing the characteristic shiny spheres (arrow heads) and radially aligned fiber cells. f) Bent Trichoplax with apposed lower epithelium. g) Time-lapse image of Trichoplax bending the epithelial borders up ward. h) Downward movement of the marginal epithelia. i) With seconds, Trichoplax extends the marginal epithelia. j) Trichoplax returns to extended position. k) Extended Trichoplax starts the gliding movement. I) Small-size open-sphere swarmer. m) Medium size open-sphere swarmer, arrow heads point to the opening. n) Cup shape swarmer. o) Spherical form of Trichoplax. p) Specimen with upper rod-like protuberance. q) Close-up showing the upper protuberance. r) Trichoplax with upper filament (arrow). s) Fluorescence image of Mito Tracker and DAPI-stained Trichoplax. t) Lyso Tracker stained lipophilic vesicles (shiny spheres); arrows point to small vesicles stained in marginal epithelium. Scale bars: $a=100 \mu \mathrm{m} ; \mathrm{m}=50 \mu \mathrm{m}$, scale apply to Fig. $\mathrm{I}$ and $\mathrm{n}$. 


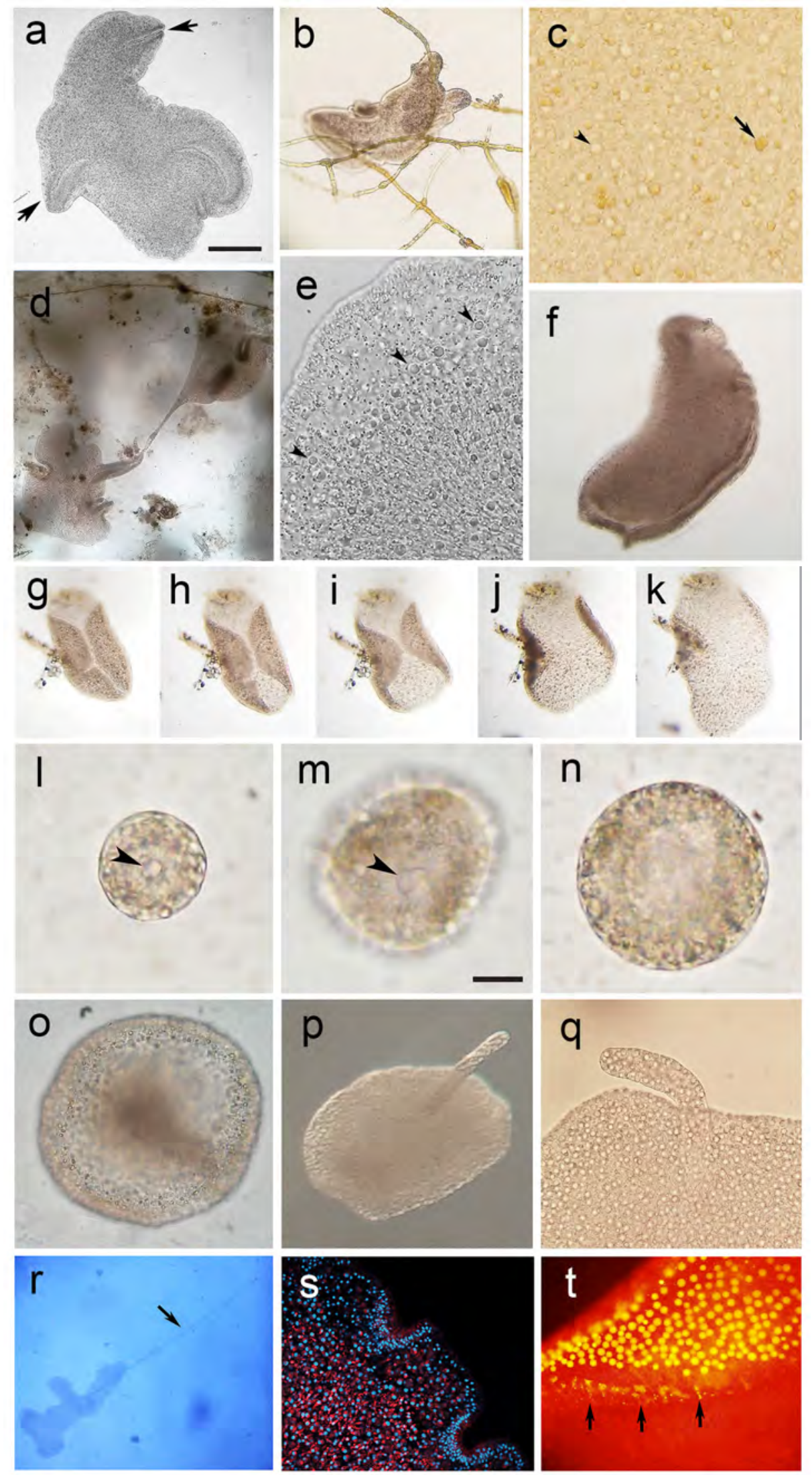




\section{REFERENCES}

Eitel, M., H. J. Osigus, R. De Salle \& B. Schierwater. 2013. Global diversity of the Placozoa. PLOS ONE 8 (4): e57131. DOl: 10.1371/journal. pone.0057131

Felder, D. L. \& D. K. Camp. 2009. Gulf of Mexico Origin, Waters, and Biota. Texas A \& M University Press. Vol1, Biodiversity. 1th ed.Texas. 1393 p. DOI: $10.1086 / 659907$

Grell, K. \& E. López-Ochoterena. 1987. A new record of Trichoplax adhaerens (Phylum Placozoa) in the Mexican Caribbean Sea. Anales del Instituto de Ciencias del Mar y Limnología-UNAM 14: 255-256.

Ortiz-Lozano, L., H. Pérez-España, A. Granados-Barba., C.González-Gándara., A. Gutiérrez-Velazquez \& J. Martos. 2013. The reef corridor of the Southwest Gulf of Mexico: Challenges for its management and conservation. Ocean \& Coastal Management 86: 22-32. D0I: 10.1016/j. ocecoaman.2013.10.006

Simion, P., H. Philippe, D. Baurain, M. Jager, D. J. Richter, A. Di Franco, B. Roure, N. Satoh, E. Queinnec, A. Ereskovsky, P. Lapebie, E. Corre, F. Delsuc, N. KInG, G. Wörheide \& M. MAnuel. 2017. A large and consistent phylo- genomic dataset supports sponges as the sister group to all other animal. Current Biology 27: 1-10. DOI: 10.1016/j.cub.2017.02.03

Smith, C. L., F. Varoqueaux, M. Kittelmann, R. N. Azzam, B.Cooper, C. A .Winters, M. Eitel, D. Fasshauer \& T. S. Reese. 2014. Novel cell types, neurosecretory cells, and body plan of the early-diverging metazoan Trichoplax adhaerens. Current Biology 24: 1565-1572. D0l: 10.1016/j.cub.2014.05.046

Thiemann, M. \& A. Ruthmann. 1990. Spherical forms of Trichoplax adhaerens (Placozoa). Zoomorphology 110: 37-45. D0l: 10.1007/ BF01632810

Thiemann, M. \& A. Ruthmann. 1991. Alternative modes of asexual reproduction in Trichoplax adhaerens (Placozoa). Zoomorphology 110: 165-174. DOI: 10.1007/BF01632872

Voigt, 0., A. G. Coluins, V. B. Pearse, J. S. Pearse, A. Ender, H. Hadrys \& B. Schierwater. 2004. Placozoa - No longer a phylum of one. Current Biology 14: 944-945. DOI: 10.1016/j.cub.2004.10.036

Zavala-Hidalgo, J., S. L. Morey \& J. J. O'Brien. 2003. Seasonal circulation on the western shelf of the Gulf of Mexico using a high-resolution numerical model. Journal of Geophysical Research 108 (C12) :119. DOI: $10.1029 / 2003 J C 001879$ 